\title{
Optimization of Carob Shells Biomass Activation by Nitric Acid for Heavy Metals Sequestration from Contaminated Water
}

\author{
Meryem Farnane ${ }^{1}$, Aicha Machrouhi ${ }^{1}$, Mohamed Abdennouri ${ }^{1}$, Hanane Tounsadi ${ }^{2}$, Zakia Rais ${ }^{2}$, \\ Samir Qourzal ${ }^{3}$, Noureddine Barka ${ }^{1, * \text { iD }}$ \\ 1 Sultan Moulay Slimane University of Béni Mellal, MRI lab, research group SEMA, FP Khouribga, Morocco; \\ farnane.meryem@gmail.com (M.F.); machrouhi.aicha90@gmail.com (A.M.); abdennourimohamed@yahoo.fr (M.A.); \\ 2 Laboratoire d'Ingénierie, d'Electrochimie, de Modélisation et d'Environnement, Université Sidi Mohamed Ben Abdellah, \\ Faculté des Sciences Dhar El Mahraz, Fès, Morocco; hananetounsadi@gmail.com (H.T.); zakia.rais@ usmba.ac.ma (Z.R.); \\ 3 Equipe de Catalyse et Environnement, Faculté des Sciences, Université Ibn Zohr, B.P. 8106 Cité Dakhla, Agadir, Morocco; \\ samir_qourzal@yahoo.fr (S.Q.); \\ * Correspondence: barkanoureddine@yahoo.fr (N.B.);
}

Received: 14.08.2021; Revised: 28.09.2021; Accepted: 2.10.2021; Published: 02.11.2021

\begin{abstract}
This study reports the use of agro-waste (carob shells) as a precursor for the synthesis of activated carbon by nitric acid activation. The prepared adsorbent was used for the removal of cadmium and cobalt ions from aqueous media. In order to optimize the preparation conditions for the high removal efficiency of heavy metals, the Box-Behnken design was used to correlate activation agent ratio $\mathrm{g}\left(\mathrm{HNO}_{3}\right) / \mathrm{g}($ carbon $)$, reaction time, and activation temperature to the removal efficiency of metals. The experimental result shows that the rise in activation temperature strongly decreases the removal of both metals. This result suggests a low energy demand for the activation of carob shells by $\mathrm{HNO}_{3}$. The sample prepared at optimum conditions was characterized by DRX, SEM, FTIR, and surface groups titrations in order to obtain information on its structural, morphological, and surface properties. It has also been found that equilibrium data are well correlated to the Langmuir model with adsorption capacities of 125.52 and $69.01 \mathrm{mg} / \mathrm{g}$, respectively, for Cd(II) and Co(II).
\end{abstract}

Keywords: agro-waste; heavy metals; remediation; experimental design.

(C) 2021 by the authors. This article is an open-access article distributed under the terms and conditions of the Creative Commons Attribution (CC BY) license (https://creativecommons.org/licenses/by/4.0/).

\section{Introduction}

Heavy metals have been frequently detected in effluent wastewaters from many industries. These effluents are associated with risks to aquatic environments [1]. Heavy metals' pollution of aquatic environments is of great concern worldwide because of their direct toxicity or bioaccumulation in living organisms, which can further alter their biological mechanisms. The concentration of heavy metals in the food chain can lead to severe nuisances to human health and aquatic ecosystems [2]. For these reasons, the removal of metals from industrial effluents is highly recommended. Several techniques have been employed to eliminate metals from water, such as precipitation, coagulation, membrane filtration, phytoremediation, and adsorption [3-7]. Among them, adsorption is the most efficient method due to its simple operation process and cost-efficiency. Activated carbon is the most known and efficient adsorbent for removing metal ions, but its high cost and regeneration difficulties restrict its use at a large scale. However, researchers have made conscientious efforts to produce more 
effective and eco-friendly activated carbons [8-10]. They have used various approaches in the preparation based on physical or chemical activation. The chemical activation method needs lower energy consumption, produces activated carbons with higher yield and well-developed microporosities [11] by using various chemical activation agents. Moreover, several agricultural by-products materials were used as precursors for the preparation of activated carbons such as apricot stone [12], pistachio shells [13], corn cobs and luffa sponge [14], Manihot esculenta [15], Tithonia diversifolia stalk, and Theobroma cacao pod [16], tabah bamboo [17], Thapsia transtagana stems [18] and Palmae biomass [19].

This study aims the prepare activated carbons from carob shells by $\mathrm{HNO}_{3}$ activation at low temperature. The box-Behnken design was used to optimize the preparation conditions based on impregnation ratio, activation time, and activation temperature. Two responses were analyzed, which are the adsorption capacity for cadmium and cobalt ions. Samples of activated carbon produced at the optimal conditions were characterized by the FTIR, XRD, SEM, Boehm titration, and the point of zero charges ( $\mathrm{pH}$ PZC). The isotherm data were correlated to Freundlich and Langmuir isotherm models.

\section{Materials and Methods}

\subsection{Materials.}

Analytical grade chemicals were used in this study. Cobalt nitrates $\left(\mathrm{Co}\left(\mathrm{NO}_{3}\right)_{2} \cdot 6 \mathrm{H}_{2} \mathrm{O}\right.$, $98 \%)$, cadmium nitrates $\left(\mathrm{Cd}\left(\mathrm{NO}_{3}\right)_{2} \cdot 4 \mathrm{H}_{2} \mathrm{O}, 98 \%\right)$, hydrochloric acid $(\mathrm{HCl}, 37 \%)$, sodium chloride $(\mathrm{NaCl}, 99.5 \%)$, sodium carbonate $\left(\mathrm{Na}_{2} \mathrm{CO}_{3}\right)$, sodium hydrogenocarbonate $\left(\mathrm{NaHCO}_{3}\right)$, and sodium thiosulfate $\left(\mathrm{Na}_{2} \mathrm{~S}_{2} \mathrm{O}_{3} \cdot 5 \mathrm{H}_{2} \mathrm{O}\right)$ were obtained from Sigma-Aldrich (Germany). Nitric acid $\left(\mathrm{HNO}_{3}, 65 \%\right)$ was provided from Sharlau (Spain). Sodium hydroxide $(\mathrm{NaOH})$ from Merck (Germany) and potassium iodide (KI) were purchased from Pharmac (Morocco).

\subsection{Preparation of activated carbon.}

The carob shells were purchased from the local market in the city of Khenifra in Morocco. They were repeatedly washed, dried, crushed, and sieved to particles of size in the range of 1-2 mm. To prepare activated carbons, $10 \mathrm{~g}$ of the powder was mixed with $50 \mathrm{~mL}$ of a solution of nitric acid with a concentration corresponding to the desired activation agent ratio $\left(\mathrm{g}\left(\mathrm{HNO}_{3}\right) / \mathrm{g}\right.$ carob shells) of $0.1,0.2$, or $0.3 \mathrm{~g} / \mathrm{g}$ and then oven-dried at $105{ }^{\circ} \mathrm{C}$ overnight to remove excess moisture. Thereafter, the impregnated powder was thermally activated in a tubular furnace under nitrogen flow at 400,500 , or $600{ }^{\circ} \mathrm{C}$ for $1,1.5$, or 2 hours. The obtained solids were washed by water several times, dried, and stirred for further use in the characterization and adsorption experiments.

\subsection{Characterization.}

FTIR spectra of the sample in the region of $4000-500 \mathrm{~cm}^{-1}$ were recorded on a ScotechSP-1 spectrophotometer using $\mathrm{KBr}$ disks. Boehm titrations were used to quantify surface basic and acidic groups of the activated carbon [20]. The $\mathrm{pH}$ point of zero charges ( $\mathrm{pH}$ PZC) was determined by the method proposed by Noh and Schwarz [21]. Scanning electron microscopy (SEM) was used to observe the morphological characteristics of the sample using an FEI Quanta 200 model. Crystallographic properties were examined by X-ray diffraction (XRD). 
The patterns were recorded in $2 \theta$ range of $10-70^{\circ}$ using a Bruker-axs D2-phaser advance diffractometer.

\subsection{Adsorption tests of metals.}

Adsorption experiments were carried out in a series of beakers of $100 \mathrm{~mL}$ containing $50 \mathrm{~mL}$ of metal ion solution with a concentration of $100 \mathrm{mg} / \mathrm{L}$ and a mass of activated carbon of $50 \mathrm{mg}$. The solutions were agitated for $3 \mathrm{~h}$ at a stirring speed of $500 \mathrm{rpm}$ using a magnetic stirrer. During experiments, the $\mathrm{pH}$ of the solutions was maintained constant at 6.50 with the addition of small amounts of either $0.1 \mathrm{M}$ of $\mathrm{NaOH}$ or $\mathrm{HCl}$ and measured by a sensION+ $\mathrm{PH} 31$ $\mathrm{pH}$ meter. After the required reaction time, the mixtures were centrifugated for $10 \mathrm{~min}$ at 3000 rpm, and the residual concentrations of metal ions were determined using an AAnalyst 200 type PerkinElmer SAA spectrophotometer.

The adsorption capacity $(\mathrm{mg} / \mathrm{g})$ of the activated carbons at equilibrium was calculated from the ratio of the difference between initial and residual metal ions concentrations $(\mathrm{mg} / \mathrm{L})$ to the mass ratio of activated carbon $(\mathrm{g} / \mathrm{L}$ ). Adsorption isotherm for the activated carbon prepared at optimum conditions was established for different metals concentrations between 20 and $200 \mathrm{mg} / \mathrm{L}$. The obtained data were correlated to Freundlich and Langmuir models by non-linear fitting using Origin 6.0 software.

\subsection{Design of experiments.}

17 experiments were planified in order to optimize the preparation conditions and evaluate the elimination efficiency of cadmium and cobalt ions by the Box-Behnken model. The factors studied and their experimental levels as shown in Table 1. The Design Expert 8.0.7.1 Trial software was used to generate the statistical experimental design and analyze the observed data. The obtained responses (adsorption capacity of cobalt or cadmium) were correlated to experimental conditions using a second-order polynomial equation (Eq.1). Considering all the linear terms, square terms, and linear interaction items, the quadratic response model, can be described as :

$Y=a_{0}+a_{1} X_{1}+a_{2} X_{2}+a_{3} X_{3}+a_{12} X_{1} X_{2}+a_{13} X_{1} X_{3}+a_{23} X_{2} X_{3}+a_{11} X_{1}^{2}+a_{22} X_{2}^{2}+a_{33} X_{3}^{2}$ where $\mathrm{Y}$ is the responses (adsorption capacity of $\mathrm{Cd}(\mathrm{II})\left(\mathrm{Y}_{1}\right)$ or $\mathrm{Co}(\mathrm{II})\left(\mathrm{Y}_{2}\right)$ ).

Table 1. Process factors and their experimental levels.

\begin{tabular}{l|ccl}
\multirow{2}{*}{ Factors } & \multicolumn{3}{|c}{ Levels } \\
\cline { 2 - 4 } & $\mathbf{- 1}$ & $\mathbf{0}$ & $\mathbf{+ 1}$ \\
\hline $\mathrm{X}_{1}:$ Impregnation ratio $(\mathrm{g} / \mathrm{g})$ & 0.1 & 0.2 & 0.3 \\
$\mathrm{X}_{2}:$ Activation time $(\mathrm{h})$ & 1 & 1.5 & 2 \\
$\mathrm{X}_{3}$ : Activation temperature $\left({ }^{\circ} \mathrm{C}\right)$ & 400 & 500 & 600
\end{tabular}

\section{Results and Discussion}

\subsection{Process optimization.}

\subsubsection{Experimental results.}

Table 2 shows the experimental matrix of the combination of factors in coded and real values and the corresponding experimental results for the two responses studied; the elimination efficiency of cadmium ( $\left.\mathrm{Y}_{1}\right)$ and cobalt (Y2). From the table, it could be seen that the activation temperature has a strong influence on the adsorption of the two metals. The 
highest adsorption capacities of $59.25 \mathrm{mg} / \mathrm{g}$ for cadmium and $50.66 \mathrm{mg} / \mathrm{g}$ for cobalt were obtained for an activated carbon impregnated by nitric acid with an impregnation ratio of 0.1 $\mathrm{g} / \mathrm{g}$ and activated for 1 hour at the temperature of $500^{\circ} \mathrm{C}$.

The model parameters for each factor's main effect and the linear interactions between factors for the two responses are shown in Table 3. The table indicates that cadmium removal is positively affected by the impregnation ratio and activation time. However, the adsorption of cobalt ions is negatively affected by these two factors. In contrast, the activation temperature presents a negative effect on both responses. The analysis of the interaction effects indicates a significant interaction between the impregnation ratio and the activation time $\left(a_{12}=9.20\right)$ with a positive effect on the elimination of cadmium and a significant interaction between the impregnation ratio and activation temperature for cobalt removal a negative effect $\left(a_{13}=-9.75\right)$.

Table 2. Design matrix in coded and real values and responses obtained for each experiment.

\begin{tabular}{l|c|c|c|c|c|c|c|c}
\multirow{2}{*}{ Exp } & \multicolumn{3}{|c|}{ Coded } & \multicolumn{3}{c|}{ Real } & \multicolumn{2}{c}{ Responses $(\mathbf{m g} / \mathbf{g})$} \\
\cline { 2 - 8 } & $\mathbf{X}_{\mathbf{1}}$ & $\mathbf{X}_{\mathbf{2}}$ & $\mathbf{X}_{\mathbf{3}}$ & $\mathbf{X}_{\mathbf{1}}$ & $\mathbf{X}_{\mathbf{2}}$ & $\mathbf{X}_{\mathbf{3}}$ & $\mathbf{Y}_{\mathbf{1}}$ & $\mathbf{Y}_{\mathbf{2}}$ \\
\hline 1 & -1 & 0 & -1 & 0.1 & 1.5 & 400 & 36.89 & 30.07 \\
\hline 2 & 0 & 0 & 0 & 0.2 & 1.5 & 500 & 47.45 & 44.78 \\
\hline 3 & 1 & -1 & 0 & 0.3 & 1 & 500 & 36.27 & 27.87 \\
\hline 4 & 0 & -1 & -1 & 0.2 & 1 & 400 & 34.41 & 33.75 \\
\hline 5 & -1 & -1 & 0 & 0.1 & 1 & 500 & 59.25 & 50.66 \\
\hline 6 & 1 & 0 & -1 & 0.3 & 1.5 & 400 & 44.35 & 35.96 \\
\hline 7 & 0 & 0 & -1 & 0.2 & 1.5 & 400 & 54.29 & 21.99 \\
\hline 8 & 0 & 1 & 0 & 0.2 & 2 & 500 & 40.00 & 24.93 \\
\hline 9 & -1 & 1 & 0 & 0.1 & 2 & 500 & 30.68 & 42.57 \\
\hline 10 & 0 & 1 & 1 & 0.2 & 2 & 600 & 21.37 & 28.60 \\
\hline 12 & 1 & 1 & 0 & 0.3 & 2 & 500 & 49.94 & 15.37 \\
\hline 13 & -1 & 0 & 1 & 0.1 & 1.5 & 600 & 28.20 & 46.25 \\
\hline 14 & 0 & 1 & -1 & 0.2 & 2 & 400 & 53.04 & 32.28 \\
\hline 16 & 0 & 0 & 1 & 0.2 & 1.5 & 600 & 26.96 & 19.78 \\
\hline 17 & 0 & -1 & 1 & 0.2 & 1 & 600 & 25.03 & 25.66 \\
\hline 15 & 1 & 0 & 1 & 0.3 & 1.5 & 600 & 29.44 & 13.16
\end{tabular}

Table 3. Values of the model coefficients obtained for the two responses.

\begin{tabular}{l|l|l} 
Coefficients & $\mathbf{Y}_{\mathbf{1}}$ & $\mathbf{Y}_{\mathbf{2}}$ \\
\hline $\mathrm{a}_{0}$ & 46.78 & 34.09 \\
\hline $\mathrm{a}_{1}$ & 2.46 & -10.06 \\
\hline $\mathrm{a}_{2}$ & 0.75 & -3.60 \\
\hline $\mathrm{a}_{3}$ & -10.51 & -1.90 \\
\hline $\mathrm{a}_{12}$ & 9.20 & -2.08 \\
\hline $\mathrm{a}_{13}$ & -1.56 & -9.75 \\
\hline $\mathrm{a}_{23}$ & -5.47 & 0.68 \\
\hline $\mathrm{a}_{11}$ & 0.04 & 1.03 \\
\hline $\mathrm{a}_{22}$ & -5.05 & 0.62 \\
\hline $\mathrm{a}_{33}$ & -8.71 & -6.93
\end{tabular}

\subsubsection{ANOVA analysis.}

The analysis of variance (ANOVA) at $95 \%$ confidence domain was performed to determine significant terms of main and interaction effects on both responses. After rejecting the insignificant terms, the ANOVA data obtained for removing cadmium and cobalt ions are presented in Table 4 and Table 5. We can observe from the tables that the three individual factors significantly affect the removal of both metals ions. In addition, The interaction between the activation time and the impregnation ratio and the interaction between the activation temperature and the activation time is the most significant interactions for cadmium ions adsorption. For the adsorption of cobalt ions, the most significant interactions are between the activation time and the impregnation ratio and between the activation temperature and the 
impregnation ratio. The quadratic interaction of the activation temperature has a significant effect on the adsorption of both metal ions. From the sum of the squares, we can conclude that the activation temperature is the most influential factor for cadmium removal, and the impregnation ratio is the most influential factor for cobalt removal.

Equations 2 and 3 show that the impregnation ratio, the activation time, and the interaction between the impregnation ratio and the activation time showed a positive effect on the adsorption of cadmium ions. On the other hand, the other factors and interactions present a negative effect. As a result, cadmium adsorption decreased as the activation temperature varied from low to high levels. For cobalt removal, all individual factors and significant interactions have a negative effect. The adsorption of cobalt increases if the activation time, the impregnation ratio, and the activation temperature are at their low levels.

$$
\begin{aligned}
& Y_{1}=42.32+2.46 X_{1}+0.22 X_{2}-10.51 X_{3}+9.20 X_{1} X_{2}-5.47 X_{2} X_{3}-6.87 X_{3}^{2} \\
& Y 2=35.23-10.06 X_{1}-3.58 X_{2}-2.06 X_{3}-2.08 X_{1} X_{2}-0.75 X_{1} X_{3}-7.34 X_{3}^{2}
\end{aligned}
$$

\begin{tabular}{l|c|c|c|c|c|c}
\multicolumn{8}{c}{ Table 4. Results of ANOVA analysis for the adsorption cadmium ions. } \\
Source & Sum of squares & Df & $\begin{array}{c}\text { Mean } \\
\text { Square }\end{array}$ & F value & $\begin{array}{c}\text { p-value } \\
\text { Prob>F }\end{array}$ & \\
\hline Model & 1543.32 & 6 & 257.22 & 5.03 & 0.012 & Significant \\
$\mathrm{X}_{1}$ & 45.19 & 1 & 45.186 & 0.88 & 0.369 & \\
$\mathrm{X}_{2}$ & 0.53 & 1 & 0.53 & 0.01 & 0.921 & \\
$\mathrm{X}_{3}$ & 976.60 & 1 & 976.60 & 19.10 & 0.001 & \\
$\mathrm{X}_{1} \mathrm{X}_{2}$ & 365.87 & 1 & 365.87 & 7.15 & 0.023 & \\
$\mathrm{X}_{2} \mathrm{X}_{3}$ & 131.31 & 1 & 131.31 & 2.57 & 0.140 & \\
$\mathrm{X}_{3}{ }^{2}$ & 191.64 & 1 & 191.64 & 3.75 & 0.082 & \\
Residual & 511.37 & 10 & 51.14 & & & \\
Cor Total & 2054.69 & 16 & & & &
\end{tabular}

Table 5. Results of ANOVA analysis for the adsorption of cobalt ions.

\begin{tabular}{l|c|c|c|c|c|c} 
Source & $\begin{array}{c}\text { Sum of } \\
\text { squares }\end{array}$ & Df & $\begin{array}{c}\text { Mean } \\
\text { Square }\end{array}$ & F value & $\begin{array}{c}\text { p-value } \\
\text { Prob>F }\end{array}$ & \\
\hline Model & 1504.27 & 6 & 250.71 & 5.74 & 0.008 & Significant \\
$\mathrm{X}_{1}$ & 754.38 & 1 & 754.38 & 17.26 & 0.002 & \\
$\mathrm{X}_{2}$ & 134.76 & 1 & 134.76 & 3.08 & 0.110 & \\
$\mathrm{X}_{3}$ & 42.44 & 1 & 42.44 & 0.97 & 0.348 & \\
$\mathrm{X}_{1} \mathrm{X}_{2}$ & 18.62 & 1 & 18.62 & 0.43 & 0.529 & \\
$\mathrm{X}_{1} \mathrm{X}_{3}$ & 379.86 & 1 & 379.86 & 8.69 & 0.015 & \\
$\mathrm{X}_{3}{ }^{2}$ & 218.73 & 1 & 218.73 & 5.01 & 0.049 & \\
Residual & 437.01 & 10 & 43.70 & & & \\
Cor Total & 1941.28 & 16 & & & &
\end{tabular}

\subsubsection{RSM analysis.}

The response surface methodology (RSM) was used to present the variations of the responses according to only 2 factors at a time, while the other factors were set to a fixed value. The 3D surfaces representation of the significant interactions is shown in Figure 1. From Figure 1a, it's clear that the adsorption of cadmium increases with increasing activation time and impregnation ratio while fixing the activation temperature at $400^{\circ} \mathrm{C}$. The representation of the interaction between the activation time and the activation temperature shown in Figure $1 \mathrm{~b}$ indicates that with an activation time of $2 \mathrm{~h}$ and an activation temperature of $400^{\circ} \mathrm{C}$, the retention of cadmium was maximal. In the case of cobalt, Figure 1c illustrates the interaction between the activation time and impregnation ratio. The figure indicates that the adsorption of cobalt increases regardless of the activation time with an impregnation ratio of $0.1 \mathrm{~g} / \mathrm{g}$. In addition, Figure $1 \mathrm{~d}$ shows that the maximum elimination of cobalt is obtained when $0.1 \mathrm{~g} / \mathrm{g}$ of impregnation ratio was used and the sample was activated at $500^{\circ} \mathrm{C}$. 

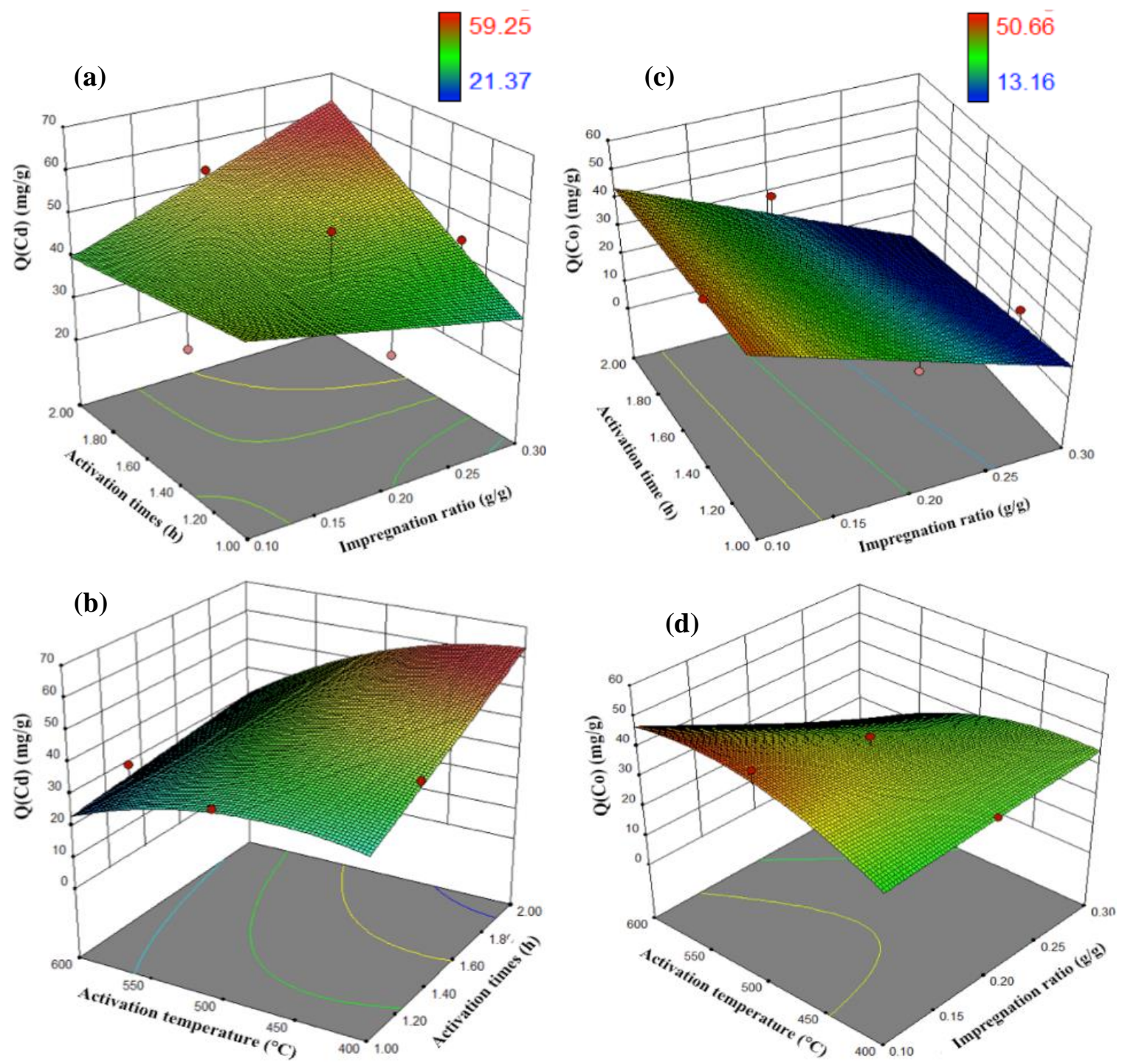

Figure 1. 2D surface plot for the adsorption of $\mathrm{Cd}(\mathrm{II})$ (a-b) and the adsorption of $\mathrm{Co}(\mathrm{II})$ (c-d).
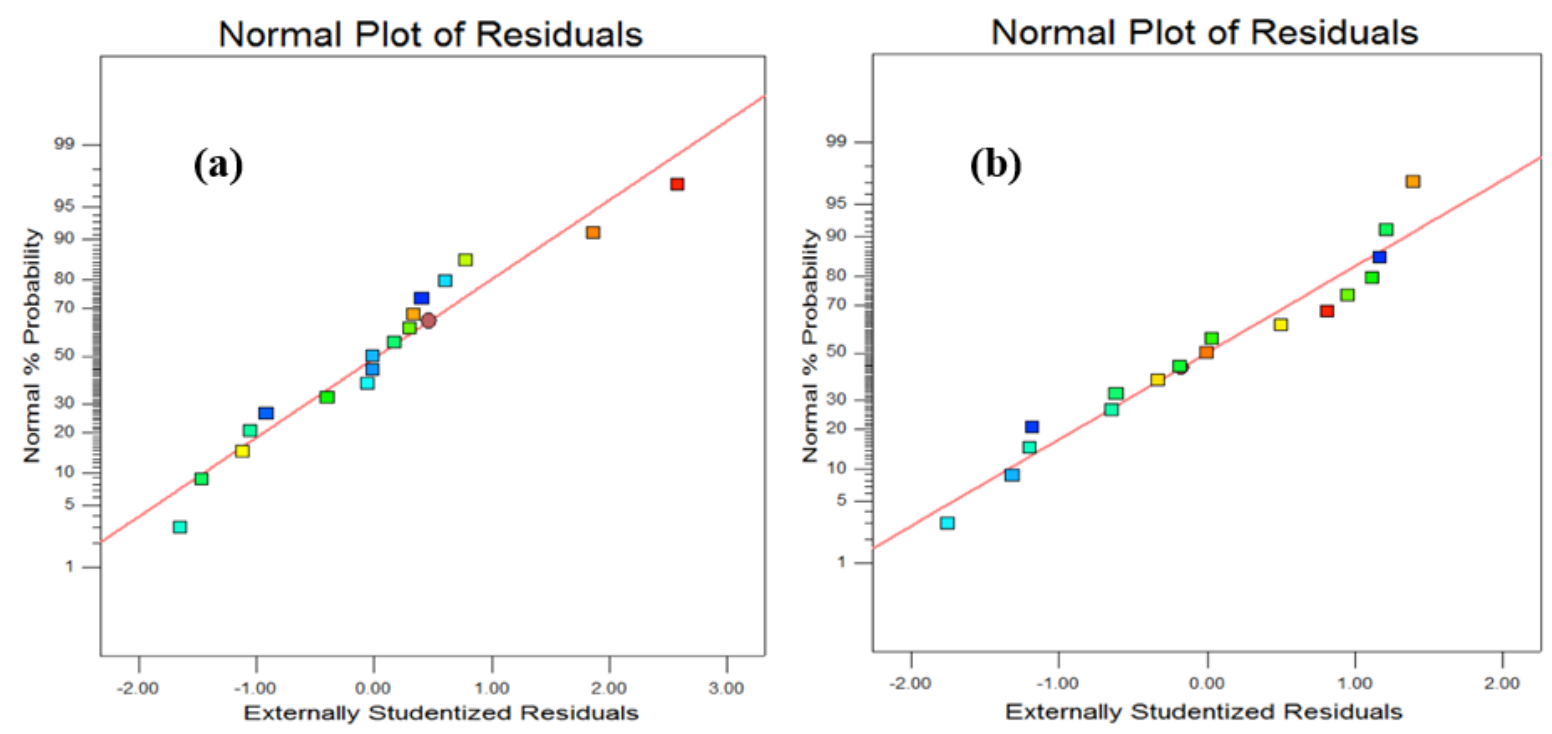

Figure 2. Normal probability plots of residuals for the two responses: (a) $\mathrm{Cd}(\mathrm{II})$ and (b) $\mathrm{Co}(\mathrm{II})$ removal. 


\subsubsection{Normal probability plot of residuals.}

The robustness of the models was judged by comparison of the experimental results with the predicted results using the linear regression curve. It is evident that the closer experimental values are to the predicted values, the models are more relevant. The linear regression curves for the adsorption of cadmium and cobalt are shown in Figure 2. It can be seen from these graphs that the alignment of the point clouds is very close to the straight line (shown in solid line), and the more the $\mathrm{R}^{2}$ tends towards 1 , which testifies to the robustness of the model.

\subsection{Characterization of optimum activated carbon.}

\subsubsection{Surface chemical properties.}

FTIR analysis results of carob shells activated by nitric acid are shown in Figure 3. The spectrum revealed the absence of any well-identified band, which confirms the high degree of activation of the shells. The low-intensity peaks around $3415 \mathrm{~cm}^{-1}$, corresponding to $\mathrm{O}-\mathrm{H}$ stretching vibration, indicate a high level of activation of the sample [22]. The peak of about $3500 \mathrm{~cm}-1$ is attributed to non-bonded alcohols, phenols, and carboxylic acids. The bands around $1610 \mathrm{~cm}^{-1}$ are characteristic of stretching vibrations of the $\mathrm{C}=\mathrm{O}$ bond in ketones, aldehydes, lactones, or carboxyl groups. This suggests that surface functional groups enrich the activated carbon. The Boehm titration result shown in Table 6 indicates that the activated carbon surface is mainly constituted by phenolic, lactonic, and carboxylic groups. These results confirm that $\mathrm{HNO}_{3}$ activation provides an increase in the number of acid groups present at the surface of activated carbon, as obtained in other studies [23, 24]. In contrast, the basicity of the activated carbon is due to oxygen-free and Lewis basic sites on the graphene layer and from some carbonyls, pyrone, and chromene type structures [25]. Table 6 also shows that the sample's pH point of sero charge was found to be 6.19. This value is in good agreement with the results of the Boehm titrations.

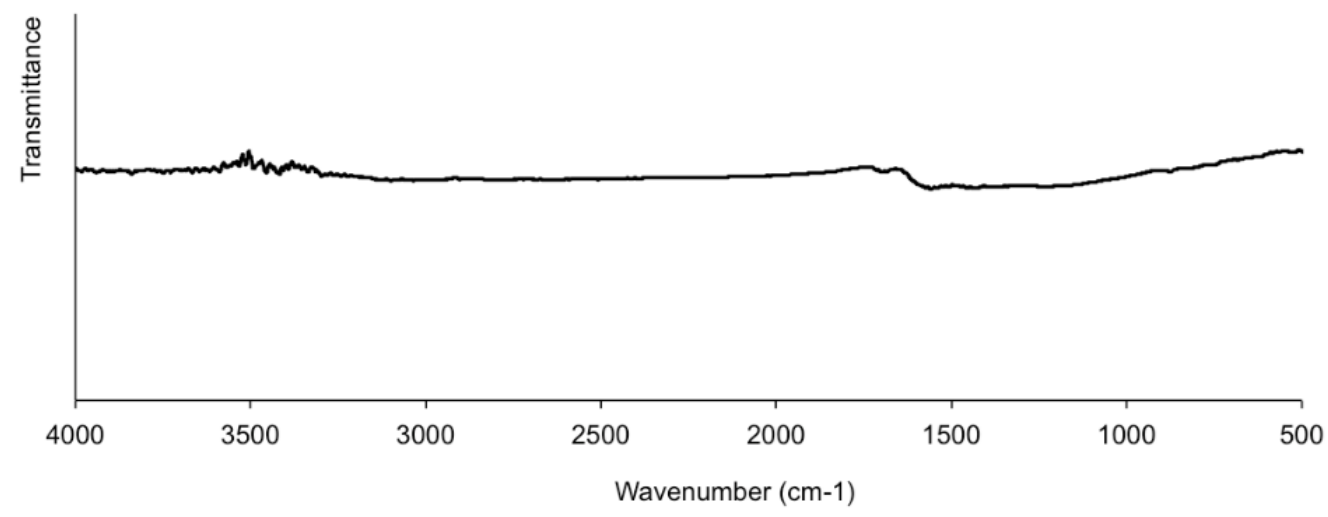

Figure 3. FTIR spectrum of nitric acid-activated carob shells: $0.1 \mathrm{~g} / \mathrm{g}-1 \mathrm{~h}-500^{\circ} \mathrm{C}$.

Table 6. Boehm titration of surface groups and pHpzc of the activated carbon.

\begin{tabular}{l|l|l|l|l|l}
\multicolumn{5}{c}{ Functional groups $(\mathbf{m e q} / \mathbf{g})$} & pHpzc \\
\hline Carboxylic & Lactonic & Phenolic & Total acid & Total basic & \\
\hline 0.4550 & 0.4990 & 0.5080 & 1.4620 & 0.4430 & 6.19
\end{tabular}




\subsubsection{Surface morphological properties.}

The particle size, shape, and porosity of the activated carbon were observed SEM. SEM image of carob shells activated by nitric acid is shown in Figure 4. We can see from the figure that the sample presents a heterogeneous surface structure with irregular pores. The external surface has many cavities and pores of different sizes, indicating that the chemical activation with the nitric acid developed the porosity of the shells. The activation provided the creation of many pores with varied sizes and forms, which can facilitate the sorption of metals, as found previously.

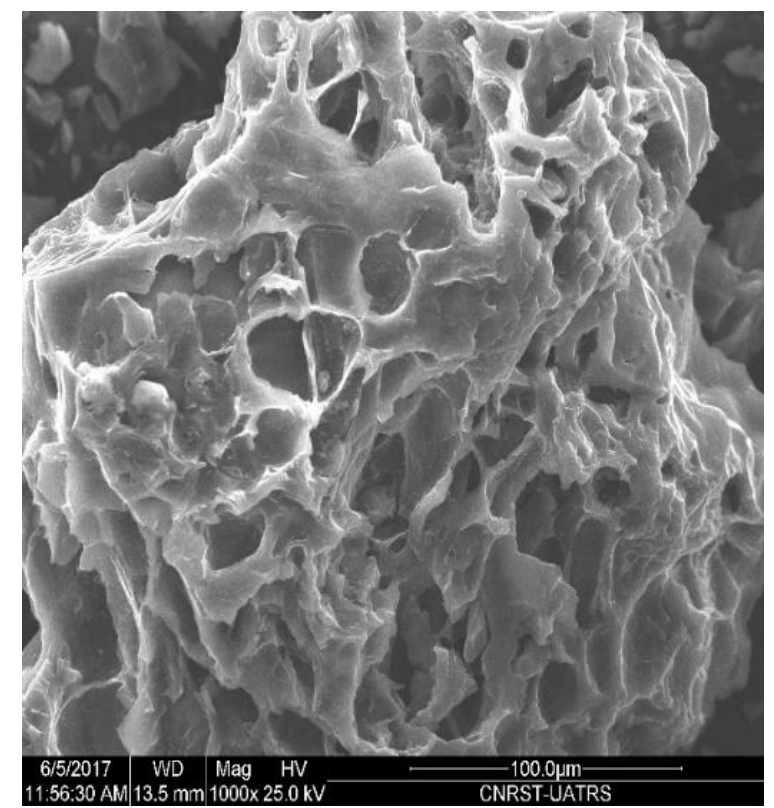

Figure 4. SEM micrographs of $\mathrm{AC}-\mathrm{HNO}_{3}: 0.1 \mathrm{~g} / \mathrm{g}-1 \mathrm{~h}-500^{\circ} \mathrm{C}$.

\subsubsection{Surface morphological properties.}

The XRD pattern of nitric acid-activated carbon shells is shown in Figure 5. From the figure, we can observe an amorphous phase for the sample characteristic of well-developed activated carbons. We can also observe two peaks, around $2 \theta$ of $29^{\circ}$ and $2 \theta$ of $43^{\circ}$, which are attributed to the 002 plane and the 110 plane reflection of disordered graphitic structure [26].

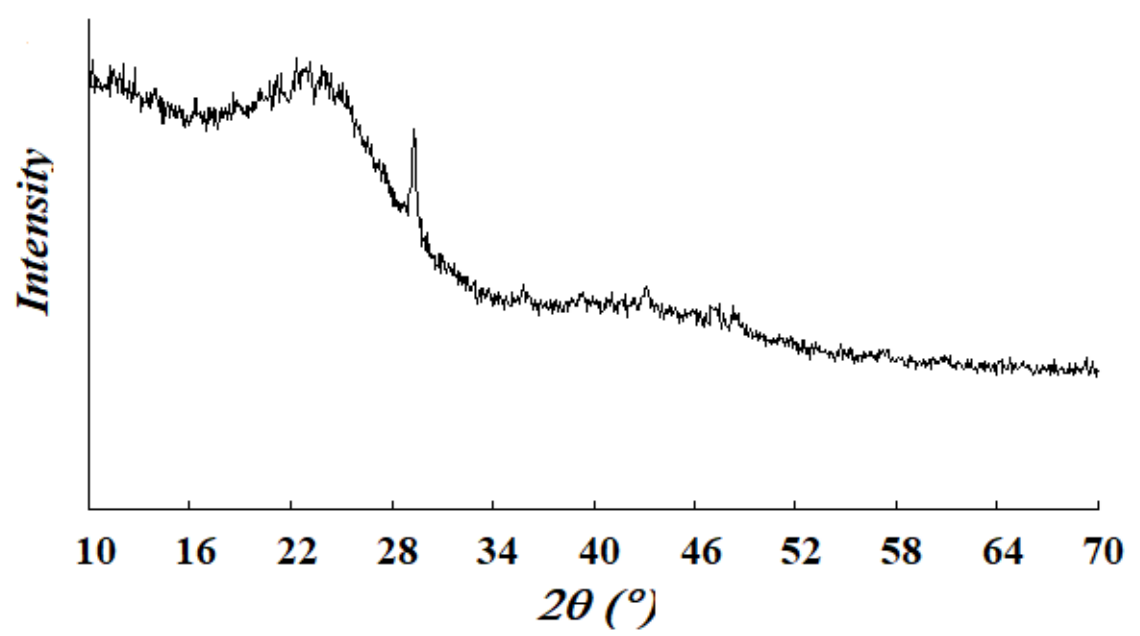

Figure 5. XRD patterns of $\mathrm{AC}^{-} \mathrm{HNO}_{3}: 0.1 \mathrm{~g} / \mathrm{g}-1 \mathrm{~h}-500^{\circ} \mathrm{C}$. 


\subsubsection{Adsorption isotherms modeling.}

The adsorption isotherm indicates how adsorbate molecules are distributed on the solid/liquid interface when the chemical equilibrium is reached, beyond providing important information about the adsorption capacity of the activated carbon. The adsorption isotherms are shown in Figure 6. From the figure, we observe that the equilibrium sorption of metal ions increased with a rise in their equilibrium concentration due to a high driving force for mass transfer at a high concentration of metals in solution [10].

The equilibrium data were fitted to the Langmuir isotherm model (Eq.4) [27] to estimate maximum sorption capacity and the Freundlich model (Eq.5) [28] to estimate the sorption intensity of the activated carbon. The corresponding equations of the two models are as follow:

$$
\begin{aligned}
& q_{\mathrm{e}}=\frac{q_{\mathrm{m}} K_{\mathrm{L}} C_{\mathrm{e}}}{1+K_{\mathrm{L}} C_{\mathrm{e}}} \\
& q_{\mathrm{e}}=K_{\mathrm{F}} C_{\mathrm{e}}^{1 / n}
\end{aligned}
$$

where $\mathrm{q}_{\mathrm{m}}(\mathrm{mg} / \mathrm{g})$ is the maximum monolayer adsorption capacity, $\mathrm{K}_{\mathrm{L}}(\mathrm{L} / \mathrm{mg})$ is the Langmuir equilibrium constant related to the adsorption affinity, and $\mathrm{Ce}$ is the equilibrium concentration, $\mathrm{k}_{\mathrm{F}}\left(\mathrm{mg}^{1-1 / \mathrm{n}} / \mathrm{g} / \mathrm{L}^{\mathrm{n}}\right)$ is the Freundlich constant, and $\mathrm{n}$ is the heterogeneity factor. The $\mathrm{K}_{\mathrm{F}}$ value is related to the adsorption capacity, while $1 / \mathrm{n}$ value is related to the adsorption intensity.

The non-linear model's adjustments are shown in Figure 6, and the obtained parameters for each model are listed in Table 7. According to the table, the closer correlation coefficient to unity obtained for the Langmuir model $\left(\mathrm{R}^{2}=0.999\right)$ suggests its suitability to describe the adsorption process of both metals in the studied concentration range. When an adsorbent exhibits a Langmuir isotherm behavior, it's supposed to contain a fixed number of sites, each of which equally adsorbs only one ion, forming thus a monolayer with the thickness of an ion [29]. On the other hand, the $\mathrm{n}$ is defined as heterogeneity factor and indicates when the adsorption process is linear $(n=1)$, physical $(n>1)$, or chemical $(n<1)$, while the ratio $1 / n$ permits to estimate the adsorption intensity, i.e., as closest to zero is the ratio value, more the surface porosity is heterogeneous. The determined values of $1 / \mathrm{n}$ were 0.64 and 0.36 , respectively, for cadmium and cobalt, indicating a high heterogeneity degree.
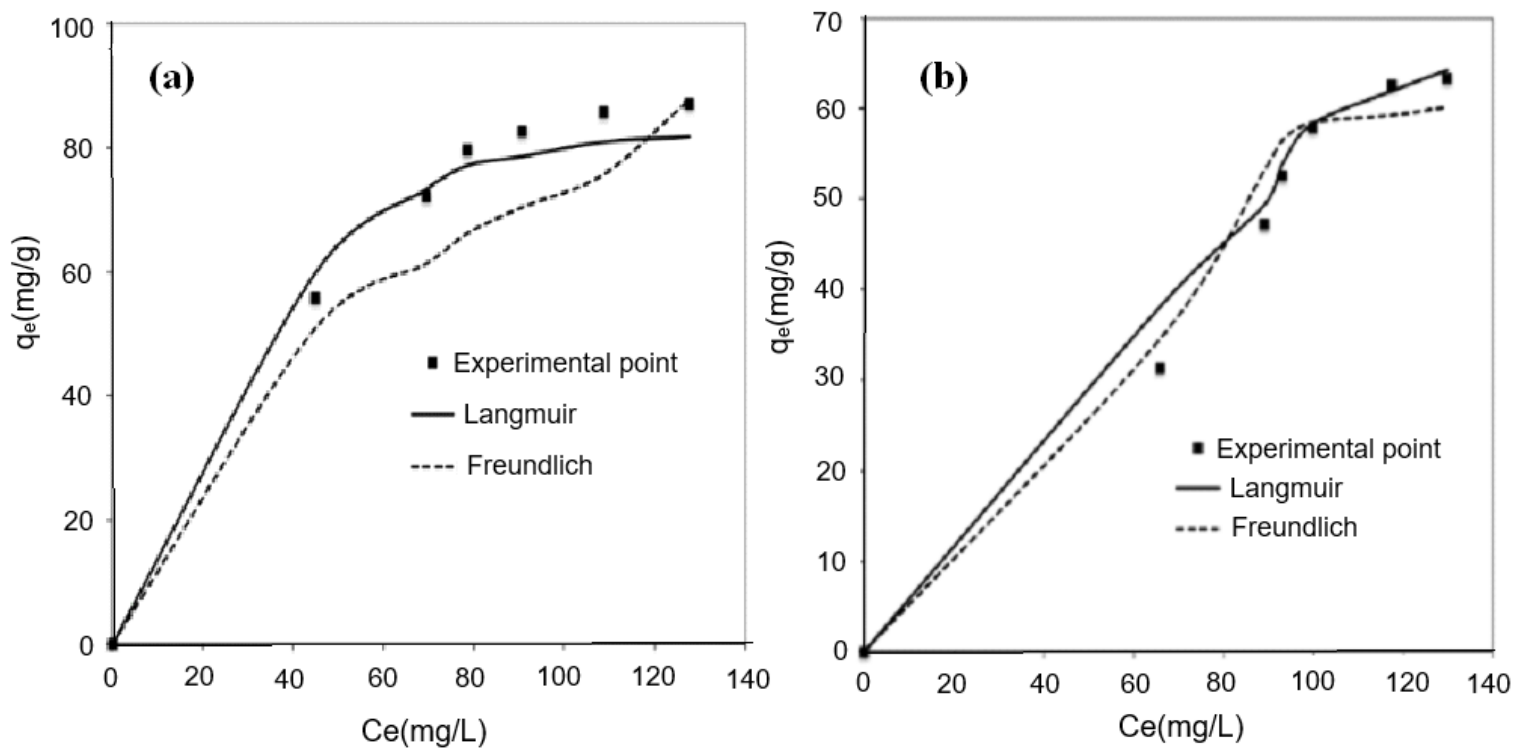

Figure 6. Nonlinear fitted isotherm curves: (a) $\mathrm{Cd}(\mathrm{II})$ and (b) $\mathrm{Co}(\mathrm{II})$. 
The adsorption capacities for both $\mathrm{Cd}(\mathrm{II})$ and $\mathrm{Co}(\mathrm{II})$ ions onto nitric acid-activated carob shells were compared with activated carbon prepared from other precursors, as shown in Table 8. The comparison shows that activated carbon has a good adsorption capacity for $\mathrm{Cd}(\mathrm{II})$ and $\mathrm{Co}$ (II) ions removal, suggesting that carob shells are promising precursors for highly efficient activated carbons.

Table 7. Constants for isotherm models of $\mathrm{Cd}(\mathrm{II})$ and $\mathrm{Co}(\mathrm{II})$ adsorption by activated carob shells.

\begin{tabular}{l|l|c|c}
\multirow{2}{*}{ Isotherms } & \multirow{2}{*}{ Parameters } & \multicolumn{2}{|c}{ AC-HNO } \\
\cline { 2 - 4 } & & $\mathrm{Cd}(\mathrm{II})$ & $\mathrm{Co}(\mathrm{II})$ \\
\hline \multirow{3}{*}{ Langmuir } & $\mathrm{q}_{\mathrm{m}}(\mathrm{mg} / \mathrm{g})$ & 125.52 & 69.01 \\
\cline { 2 - 4 } & $\mathrm{K}_{\mathrm{L}}(\mathrm{L} / \mathrm{mg})$ & 0.001 & 0.002 \\
\cline { 2 - 4 } & $\mathrm{r}^{2}$ & 0.999 & 0.995 \\
\hline \multirow{3}{*}{ Freundlich } & $\mathrm{n}$ & 1.554 & 4.156 \\
\cline { 2 - 4 } & $\mathrm{K}_{\mathrm{F}}\left(\mathrm{mg}^{1-1 / \mathrm{n}} / \mathrm{g} / \mathrm{L}^{\mathrm{n}}\right)$ & 3.878 & 10.651 \\
\cline { 2 - 4 } & $\mathrm{r}^{2}$ & 0.998 & 0.993
\end{tabular}

Table 8. Comparison of adsorption capacity of activated carbon from carob shells with other corresponding precursors.

\begin{tabular}{l|l|l|l|l} 
Precursor & Activating agent & $\mathbf{C d}(\mathbf{I I})$ & $\mathbf{C o}(\mathbf{I I})$ & Ref. \\
\hline Diplotaxis harra & $\mathrm{H}_{3} \mathrm{PO}_{4}$ & 62.58 & 82.55 & {$[9]$} \\
\hline Olive stone & $\mathrm{H}_{3} \mathrm{PO}_{4}$ & 24.38 & - & {$[30]$} \\
\hline Aguaje stones & $\mathrm{H}_{3} \mathrm{PO}_{4}$ & 26.33 & - & {$[30]$} \\
\hline APhragmites australis & $\mathrm{H}_{3} \mathrm{PO}_{4}$ & 40.42 & - & {$[31]$} \\
\hline Phragmites australis & $\left(\mathrm{NH}_{3}\right)_{3} \mathrm{PO}_{4}$ & 58.33 & - & {$[31]$} \\
\hline Phragmites australis & $\left(\mathrm{NH}_{3}\right)_{2} \mathrm{HPO}_{4}$ & 46.42 & - & {$[31]$} \\
\hline Exhausted coffee & $\mathrm{Formaldehyde}_{2}$ & 24.69 & - & {$[32]$} \\
\hline Carob shells & $\mathrm{ZnCl}_{2}$ & 85.17 & 61.29 & {$[33]$} \\
\hline Carbon oxalate-treated & $\mathrm{K}_{2} \mathrm{C}_{2} \mathrm{O}_{4}$ & - & 50.03 & {$[34]$} \\
\hline Bagasse pith & $\mathrm{H}_{2} \mathrm{SO}_{4}$ & - & 153.85 & {$[35]$} \\
\hline Apricot stone & $\mathrm{H}_{3} \mathrm{PO}_{4}$ & - & 111.11 & {$[36]$} \\
\hline Glebionis coronaria L. & $\mathrm{KOH}_{3}$ & 115.99 & 44.85 & {$[37]$} \\
\hline Glebionis coronaria L. & $\mathrm{H}_{3} \mathrm{PO}_{4}$ & 118.78 & 42.86 & {$[38]$} \\
\hline Carob shells & $\mathrm{HNO}_{3}$ & 125.52 & 9.01 & This study
\end{tabular}

\section{Conclusions}

This study cited a suitable precursor for the preparation of efficient activated carbon by nitric acid activation. The Box-Behnken design and response surface methodology were applied to determine the optimum preparation conditions for the high adsorption capacity of cadmium and cobalt ions in an aqueous solution. Three factors were chosen for the optimization; activation time, impregnation ratio, and activation temperature. The optimization approach indicated that the most influential factor on the metal ions adsorption was the activation temperature. Based on the experimental results, the maximum adsorption capacities were 59.25 and $50.66 \mathrm{mg} / \mathrm{g}$, respectively, for cadmium and cobalt. The activated carbon impregnated with a ratio of $0.1 \mathrm{~g} / \mathrm{g}$ of nitric acid and activated for 1 hour at $500^{\circ} \mathrm{C}$ gives the highest adsorption capacity for the two metals under the optimum conditions; relatively highporosity activated carbon was obtained from the carob shells.

\section{Funding}

This research received no external funding.

\section{Acknowledgments}

This research has no acknowledgment. 


\section{Conflicts of Interest}

The authors declare that there are no conflicts of interest regarding the publication of this paper.

\section{References}

1. Masindi, V.; Muedi, K.L. Environmental Contamination by Heavy Metals. IntechOpen publisher, London, UK, 2018; https://doi.org/10.5772/intechopen.76082.

2. Hidayati, N.V.; Prudent, P.; Asia, L.; Vassalo, L.; Torre, F.; Widowati, I.; Sabdono, A.; Syakti, A.D.; Doumenq, P. Assessment of the ecological and human health risks from metals in shrimp aquaculture environments in Central Java, Indonesia. Environmental Science and Pollution Research 2020, 27, 4166841687, https://doi.org/10.1007/s11356-020-09967-8.

3. Zhang, Y.; Duan, X. Chemical precipitation of heavy metals from wastewater by using the synthetical magnesium hydroxy carbonate. Water Science and Technology 2020, 81, 1130-1136, https://doi.org/10.2166/wst.2020.208.

4. Lee, A.; Kim, K. New Approach to Remove Heavy Metals from Wastewater by the Coagulation of AlginateRhamnolipid Solution with Aluminum Sulfate. Water 2020, 12, https://doi.org/10.3390/w12123406.

5. Verma, B.; Balomajumder, C.; Sabapathy, M.; Gumfekar, S.P. Pressure-Driven Membrane Process: A Review of Advanced Technique for Heavy Metals Remediation. Processes 2021, 9, https://doi.org/10.3390/pr9050752.n

6. Awa, S.H.; Hadibarata, T. Removal of Heavy Metals in Contaminated Soil by Phytoremediation Mechanism: a Review. Water Air, Soil. Pollut. 2020, 231, https://doi.org/10.1007/s11270-020-4426-0.

7. Tchakounte, A. N.; Poumve, H.Z.; Kede, C.M.; Dika, J.M. Calcareous-support nanoscale Zero-valent iron: New findings on adsorption of $\mathrm{Cr}(\mathrm{VI})$ in aqueous solution. J. Appl. Surf. Interface 2019, 6, 9-17, https://doi.org/10.48442/IMIST.PRSM/jasi-v6i1-3.17461.

8. Mariana, M.; Abdul Khalil, H.P.S.; Mistar, E.M.; Yahya, E.B.; Alfatah, T.; Danish, M.; Amayreh, M. Recent advances in activated carbon modification techniques for enhanced heavy metal adsorption. J. Water Proc. Eng. 2021, 43, https://doi.org/10.1016/j.jwpe.2021.102221.

9. Boumya, W.; Khnifira, M.; Machrouhi, A.; Abdennouri, M.; Achak, M.; Qourzal, S.; Tounsadi, H.; Barka, N. Box-Behnken design for the understand of adsorption behaviors of cationic and anionic dyes by activated carbon, Desalin. Water Treat. 2021, 212, 204-211, https://doi.org/10.5004/dwt.2021.26610.

10. Farnane, M.; Tounsadi, H.; Elmoubarki, R.; Mahjoubi, F. Z.; Elhalil, A.; Saqrane, S.; Abdennouri, M.; Qourzal, S.; Barka, N. Alkaline treated carob shells as sustainable biosorbent for clean recovery of heavy metals: Kinetics, equilibrium, ions interference and process optimisation. Ecol. Eng. 2017, 101, 9-20, https://doi.org/10.1016/j.ecoleng.2017.01.012.

11. Liu, B.; Wang, W.; Wang, N.; Aub, P.C.T. Preparation of activated carbon with high surface area for highcapacity methane storage, J. Ener. Chem. 2014, 23, 662-668, https://doi.org/10.1016/S2095-4956(14)601984.

12. Abbas, M. Modeling of adsorption isotherms of heavy metals onto Apricot stone activated carbon: Twoparameter models and equations allowing determination of thermodynamic parameters. Mater. Today: Proc. 2021, 43, 3359-3364, https://doi.org/10.1016/j.matpr.2020.05.320.

13. Nejadshafiee, V.; Islami, M.R. Intelligent-activated carbon prepared from pistachio shells precursor for effective adsorption of heavy metals from industrial waste of copper mine. Environ. Sci. Pollut. Res. 2020, 27, 1625-1639, https://doi.org/10.1007/s11356-019-06732-4.

14. El-Bendary, N.; El-Etriby, H.K.; Mahanna; H. High-performance removal of iron from aqueous solution using modified activated carbon prepared from corn cobs and luffa sponge. Desalin. Water Treat. 2021, 213, 348-357, https://doi.org/10.5004/dwt.2021.26721.

15. Belcaid; A.; Beakou, B.H.; El Hassani, K.; Bouhsina, S.; Anouar, A. Efficient removal of Cr (VI) and Co (II) from aqueous solution by activated carbon from Manihot esculenta Crantz agricultural bio-waste. Water. Sci. Technol. 2021, 83, 556-566, https://doi.org/10.2166/wst.2020.585.

16. Eletta, O.A.A.; Ayandele, F.O.; Ighalo, J.O. Adsorption of $\mathrm{Pb}$ (II) and $\mathrm{Fe}(\mathrm{II})$ by mesoporous composite activated carbon from Tithonia diversifolia stalk and Theobroma cacao pod. Biomass Conv. Bioref. 2021, https://doi.org/10.1007/s13399-021-01699-0.

17. Negara, D.N.K.P.; Nindhia, T.G.T.; Surata, I.W.; Hidajat, F.; Sucipta, M. Textural characteristics of activated carbons derived from tabah bamboo manufactured by using $\mathrm{H}_{3} \mathrm{PO}_{4}$ chemical activation. Mater. Today: Proc. 2020, 22, 148-155, https://doi.org/10.1016/j.matpr.2019.08.030.

18. Machrouhi, A.; Alilou, H.; Farnane, M.; El Hamidi, S.; Abdennouri, M.; Tounsadi, H.; Barka, N. Statistical optimization of preparing activated carbon from Thapsia transtagana stems biomass for dyes removal using central composite design (CCD). J. Sci.: Adv. Mater. Devices 2019, 4, 544-553. https://doi.org/10.3390/ma12020241. 
19. Egirani, D.E.; Poyi, N.R.; Shehata, N. Preparation and characterization of powdered and granular activated carbon from Palmae biomass for cadmium removal. Int. J. Environ. Sci. Technol. 2020, 17, 2443-2454, https://doi.org/10.1016/j.jsamd.2019.09.002.

20. Boehm, H.P. Surface oxides on carbon and their analysis: a critical assessment. Carbon 2002, 40, 145-149, https://doi.org/10.1016/S0008-6223(01)00165-8.

21. Noh, J.S.; Schwarz, J.A. Estimation of the point of zero charge of simple oxides by mass titration. Journal of Colloid and Interface Science 1989, 130, 157-164, https://doi.org/10.1016/0021-9797(89)90086-6.

22. Machrouhi, A.; Boumya, W.; Khnifira, M.; Sadiq, M.; Abdennouri, M.; Elhalil, A.; Tounsadi, H.; Qourzal, S.; Barka, N. Synthetic dyes adsorption and discoloration of a textile wastewater effluent by $\mathrm{H}_{3} \mathrm{PO}_{4}$ and $\mathrm{H}_{3} \mathrm{BO}_{3}$ activated Thapsia transtagana biomass. Desalin. Water Treat. 2020, 202, 435-449, https://doi.org/10.5004/dwt.2020.26164.

23. Beyan, S.M.; Prabhu, S.V.; Sissay, T.A., Getahun, A. Sugarcane bagasse based activated carbon preparation and its adsorption efficacy on removal of BOD and COD from textile effluents: RSM based modeling, optimization and kinetic aspects. Bioresour. Technol. Rep. 2021, 14, https://doi.org/10.1016/j.biteb.2021.100664.

24. Farnane, M.; Machrouhi, A.; Elhalil, A.; Tounsadi, H.; Abdennouri, M.; Qourzal, S.; Barka, N. Process optimization of potassium hydroxide activated carbon from carob shell biomass and heavy metals removal ability using Box-Behnken design, Desalin. Water Treat. 2018, 133, 153-166, https://doi.org/ 10.5004/dwt.2018.22977 .

25. Demiral, İ., Samdan, C.; Demiral, H. Enrichment of the surface functional groups of activated carbon by modification method. Surf. Interfaces 2021, 22, https://doi.org/10.1016/j.surfin.2020.100873.

26. Ram, K.; Abbie, N.J.; Barry, J.M. Transmission electron microscopy, Raman and X-ray photoelectron spectroscopy studies on neutron irradiated polycrystalline graphite. Rad. Phys. Chem. 2015, 107, 121-127, https://doi.org/10.1016/j.radphyschem.2014.10.005.

27. Langmuir, I. The constitution and fundamental properties of solids and liquids. J. Amer. Chem. Soc. 1916, 38, 2221-2295, https://doi.org/10.1021/ja02268a002.

28. Freundlich, H.; Heller, W. The adsorption of cis- and trans-azobenzene. J. Amer. Chem. Soc. 1939, 61, 22282230, https://doi.org/10.1021/ja01877a071.

29. Mohammadi, S.Z.; Hamidian, H.; Moeinadini, Z. High surface area-activated carbon from Glycyrrhiza glabra residue by $\mathrm{ZnCl}_{2}$ activation for removal of $\mathrm{Pb}(\mathrm{II})$ and $\mathrm{Ni}(\mathrm{II})$ from water samples. J. Ind. Eng. Chem. 2014, 20, 4112-4118, https://doi.org/10.1016/j.jiec.2014.01.009.

30. Obregon-Valencia, D.; del, M.; Sun-Kou, R. Comparative cadmium adsorption study on activated carbon prepared from aguaje (Mauritia flexuosa) and olive fruit stones (Olea europaea L.). J. Environ. Chem. Eng. 2014, 2, 2280-2288, https://doi.org/10.1016/j.jece.2014.10.004.

31. Guo, Z.; Fan, J.; Zhang, J.; Kang, Y.; Liu, H.; Jiang, L.; Zhang, C. Sorption heavy metal ions by activated carbons with well-developed microporosity and amino groups derived from Phragmites australis by ammonium phosphates activation. J. Taiwan Inst. Chem. Eng. 2016, 58, 290-296, https://doi.org/10.1016/j.jtice.2015.05.041.

32. Serrano-Gomez, J.; Lopez-Gonzalez, H.; Olguin, M.T.; Bulbulian, S. Carbonaceous material obtained from exhausted coffee by an aqueous solution combustion process and used for cobalt (II) and cadmium (II) sorption. J. Environ. Manage. 2015, 156, 121-127, https://doi.org/10.1016/j.jenvman.2015.03.013.

33. Farnane, M.; Machrouhi, A.; Khnifira, M.; Barour, M.; Elmoubarki, R.; Qourzal, S.; Tounsadi, H.; Barka, N. Zinc chloride activation of carob shells for heavy metals removal from water: statistical optimisation, characterisation and isotherm modelling. Inter. J. Environ. Anal. Chem. 2020, https://doi.org/10.1080/03067319.2020.1777290.

34. Kasaini, H.; Kekana P.T.; Saghti A.A.; Bolton, K. Adsorption Characteristics of Cobalt and Nickel on Oxalate-Treated Activated Carbons in Sulphate Media. World Academy of Science, Eng. Technol. 2013, 76, 707-721.

35. Krishnan, K.A.; Anirudhan, T.S. Kinetic and equilibrium modelling of cobalt(II) adsorption onto bagasse pith based sulphurised activated carbon. Chem. Eng. J. 2008, 137, 257-264, https://doi.org/10.1016/j.cej.2007.04.029.

36. Kaddour, S.; Abbas, M.; Trari, M. Kinetic and equilibrium studies of cobalt adsorption on apricot stone activated carbon (ASAC). Curr. Opin. Biotechnol. 2013, 24, 745-751, https://doi.org/10.1016/j.copbio.2013.05.181.

37. Tounsadi, H.; Khalidi, A.; Farnane, M.; Abdennouri, M.; Barka, N. Experimental design for the optimization of preparation conditions of highly efficient activated carbon from Glebionis coronaria L. and heavy metals removal ability. Proc. Saf. Environ. Prot. 2016, 102, 710-723, https://doi.org/10.1016/j.psep.2016.05.017.

38. Tounsadi, H.; Khalidi, A.; Machrouhi, A.; Farnane, M.; Elmoubarki, R.; Elhalil, A.; Sadiq, M.; Barka, N. Highly efficient activated carbon from Glebionis coronaria L. biomass: Optimization of preparation conditions and heavy metals removal using experimental design approach. J. Environ. Chem. Eng. 2016, 4, 4549-4564, https://doi.org/10.1016/j.jece.2016.10.020. 